\title{
THE SOCIOLOGICAL WARRANT FOR VOCATIONAL EDUCATION
}

\author{
PROFESSOR JOHN M. GILLETTE \\ University of North Dakota
}

There are several sufficient and important reasons why sociologists, and the whole group of social scientists, should interest themselves and participate in the present movement for the socialization of education. First, the subject-matter which is to form a very large part of school programmes must come out of the realms of the social sciences. This is becoming more and more evident. Not only history and civics have entered the schools, but various forms of material from the other social sciences. In order to select the best and richest of social matter for introduction some criterion of value must be formulated and used. It is the business of social scientists to become guides in this selection and particularly in the formulation of the criterion of value.

Second, not only must the social scientists be active in pronouncing what particular material from their realms of knowledge shall be incorporated in the schools, but they should have a large voice in determining what the general content of the lower reaches of education should be. The world is profoundly rich in knowledge. But a minimum of this infinitude can be presented to youths in our schools. It is evident that certain ranges of facts are more useful in life than others. The criterion of usefulness must arise out of social considerations. This criterion can only be found in the range of values. Values are social products and their relative rank must be established by scientific procedure. This function must be taken up by sociologists, who view society in its total aspects and so make a ranking of values.

Third, this consideration of the general subject-matter introduces the fundamental reason for active participation in educational matters by sociologists of all ranges of labor. The content 
of education, especially of the common schools, can be determined scientifically and therefore rightly only with reference to the exact nature and constitution of organized society. Education is a social institution. It is part of a whole set of interdependent institutions or organizations. It is the character of institutions to perform some particular service for total society on the principle of the division of labor. These functions must conserve or advance the social process, welfare, progress. A social philosophy determines the scope and function of each range of institutions. Only when this is done may it be seen when a given institution or set of organizations is performing just that service total society demands. Those who make their life-work the consideration of society as a scientific object, who understand its constitution and laws, who know the place and function of institutions and hence of individuals through these agencies relative to total society should be depended on to mark out the place and function of education. The scope of this paper chiefly falls within the limits prescribed by the last reason.

Already in the present movement toward the "socialization of education" we observe the influence of the social sciences in the character of the phrase which has come to denote present educational development as well as in the character of the movement. The phrase is well chosen to reveal the significance of the task set themselves by those interested in transforming education. For educational reformers have set out to perform no less a task than to recast the schools so that they shall not only temporarily reflect the spirit and ideals of their community and age but that they shall be organized in curricula and methods to definitely train and differentiate individuals in view of a fundamentally specialized society in its structural and functional demands. To socialize total education, therefore, would be to reconstruct and reorganize the public-school system for realizing the fundamental interests of society, for which the state assumes responsibility in the training of its citizens, and to give to each interest just that amount of recognition in time and scope its rank among the interests in actual society warrants. To socialize a given school would be to discover the dominant 
interest or interests of the community in which it is located and so to organize the training activities of the school that those trained shall be qualified to carry out the social services demanded by the community in terms of its interests.

It is the business of the sociologist to make an exposition of society in terms of its fundamental interests and to give them their ranking in the order of their relative importance in the development of society. These interests become a guide for determining what education shall do and where the emphasis shall be placed in its programme.

It is evident, to the sociologist at least, that the social environment is the dominant factor for determining what educational training shall be. Hardly any builders of educational systems at any time have wholly disregarded the world the educated being is to live in. At best, however, the close dependence of the person on the nature of the social world has been seldom appreciated. Pestalozzi saw it vividly, viewing education as he did as a means of reforming human society, but the accretions of formal pedagogy later buried his insight. More recently, the psychology of the individual has offered the basis and determining factor. But general or individual psychology gives as false a view of the person as the geocentric theory did that of the solar system.

It may be worth while to indicate the close relationship between the individual and his environment and how the social apparatus is the mediating agency between him and the ends of all his wants and activities, even conditioning his dealing with the physical environment.

A little reflection shows us that man's most immediate dependence for realizing the satisfaction of his wants is on social agencies rather than on physical conditions. It is true that ultimately the raw materials of food, clothing, shelter, permanent forms of wealth, etc., have to be extracted from nature. But two things at least are to be observed in his connection. First, social evolution has consisted in building up a network of agencies, structures, on the basis of division of labor and of occupation, which have rendered individual man the more independent of 
particular local and physical conditions the farther civilization has proceeded. Three-fifths of the population of the advanced civilizations, such as England and Germany, live in cities and even one-half of the population of a new country like the United States dwell in urban communities of two thousand or more inhabitants. The poorest of these inhabitants consume hundreds of kinds of articles they do not and cannot produce. They actually produce nothing directly from physical nature. All they have are social products borne to them and retailed to them by social agencies. Even the atmosphere and climate, the freest of nature's goods outside of meteorological conditions, are affected by social agencies. Therefore, to get at the original supply of materials for life purposes which nature furnishes man depends on and gets the use of a vast array of intermediary social machinery. Social organizations of all sorts exist to cut him off from and to connect him with nature. He can no longer exploit nature as a free individual. Political organizations in the shape of government exist to limit his attack. Originally "free goods" have become "property." Police courts and jails testify to this. Only supreme exploiters, talented and lucky individuals may now make onslaughts on mines, forests, and lands, and this is done by getting control of great social organizations. Individuals independent of social agencies do not exist in society.

Second, the dominance of the social factor is seen in the fact that by means of social agencies, improvements in the way of inventions and technique, the actual supply of material products in given areas to support life has been increased. The economic stages of society, such as the "hunting and fishing," the "pastoral," "agricultural," "commercial," "industrial," are only names to denote improved social means of getting a greater abundance of food from the earth. The "industrial revolution" together with the opening up of America almost doubled the population of Europe in the nineteenth century. England's inhabitants increased from I2 to I8 per cent. each decade, or from $8,000,000$ in 1800 , to $30,000,000$ in 1900 (Fetter, Principles of Economics, p. I94). There is no visible limit to population. When raising food by agriculture fails of further 
increase, direct and rapid production by chemical processes promises to continue it (Arena, Vol XXXI, p. I73; Popular Science, March, I907).

A further consideration would demonstrate that this same social environment is the depository of the influences which determine the peculiar personal nature of the individual and that it mediates to him, in the same manner as it does the material, the finer or spiritual goods of life. Baldwin has shown in detail how human personality is built up out of the material resident in his social group and through interplay with his colleagues. Thomas has demonstrated that the superiority of the civilized over the uncivilized man is due not to greater brain and inherent mind development but to "social heredity," to the more complex and technological social environment or medium in which he is reared.

If it is true that the individual is absolutely dependent on the social organization for the satisfaction of his material interests and that his personality is likewise dependent for its character on the spirit and reason resident in the fundamental technique of society, it becomes evident that education is unscientific and incomplete in so far as it is not organized in view of the exact nature and pointings of society.

In order to get at the place education should hold relative to society it will be necessary to discover the essential relation of the individual to organized social life. I shall seek to show that the individual's chief business is to participate in the process total society carries on by means of functioning, in a more or less specialized way, dependent on his ability and training, through the specialized agencies of society, and that the cue to his lifefunctioning is the line of his dominant or life-interest in terms of the social structure. I shall use interest in the objective, social sense so admirably designated by Professor Small (American Journal of Sociology, Vol. VI, pp. 64, 65; General Sociology, chap. xiv), and think of the special organization of society as the outcome of interests at work as he does (General Sociology, p. 233).

It appears to me that the best way to get the correct idea of the relation of the individual to organized society is to fall back 
on the historical aspect. A review of the development of human society impresses on us the valuable perception that present social structures are, in origin, occupation groups, and fundamentally so in fact, which have grown up out of the persistent attempts of men to adjust themselves to each other for the purpose of satisfying diverging human wants and primarily to realize their own life-necessities.

When we trace the development of society from a simple group or groups into a great social organization we see that it has occurred by the growing differentiation of one group into diverse parts through division of functions, or by the consolidation of various natural groups primarily and then the differentiation of the consolidated mass into separate parts, classes, or businesses. We perceive that all of this, however brought about, has been established in order that the life and welfare of one and all might be better realized. With primitive men there were few wants, and hence few vocations. The matter of adjustment was simple. To follow custom and tradition was the essential. But in developing to higher stages wants multiplied, no one individual could obtain the skill or facilities for supplying all of his wants, hence separate vocations arose in which one set of individuals prosecuted one line of business, another, another line, and so on. Each vocation disposed of its surplus goods to others of other vocations to obtain the things no longer made by themselves. Classes likewise arose to supply functions and activities not productive of material goods but needful to serving, regulating, and inspiring producers.

These groups or divisions of businesses, each almost infinitely differentiated today, constitute the social structures. They form the framework of society. They are the social organization. They are interdependent groups because no one is complete in itself any more than the nerves or muscles of a physical organism can exist as independent entities. Each individual who has a function to perform for society must use some one or various of these structures in order so to function.

A necessary perception comes by observing the growing differentiation of dominant interests of individuals to keep pace with 
the evolving structures of society and the reciprocal dependence of these interests and structures on each other. In savage society all members had about the same interests in about the same intensity. Both knowledge and economic activities were little divided and developed. Later, with the refinement of social functions, the vocational interests emerged. There appeared leaders and governors, men to charm the spirits and to be the custodians of group traditions, those who should provide food and those who should fight. In time there emerged the fundamental lines of human interests, namely, the political, the religious, the cultural and the economic.

In this development lie two important transformations. First, interests, with their corresponding occupation, become distinctly separated, so that certain persons express their dominant interests in a definite specialized vocation or profession, and by it they minister to the general social necessities or interests in this direction. Second, when society has expanded into national scope, and modern science and methods of industry have been introduced, each fundamental line of organization becomes so differentiated under the push of new demands, that individual interests may realize themselves vocationally in any one of its many phases, and hence there are many kinds of specialized servitors ministering to each of the dominant line of wants of a national society. While we have the fundamental human interests still, and each interest expresses itself by means of special institutions or organizations, society has developed for that purpose, yet each kind of institution is constituted of subordinate organizations.

Thus today we may say that everyone in society is interested in political activities, some more, some less. To meet the social interest and demands of this type there exist the political institutions and organizations. They are a group, not merely one. They are complex, not simple as formerly. In this group we have all the complicated machinery of governmental administration, legislation, and justice; political parties with their complicated organizations and agencies; constitutions, codes, and customs of law. Some men are fundamentally interested in political institutions and devote themselves to some phase of political life voca- 
tionally. All members of our society are interested in our political institutions, secondarily, in that a certain and definite range of their social needs finds satisfaction through them, and their wants are ministered to by the professionals in politics.

In the same manner the economic line of activities has become highly diversified. It is no longer merely food-getting and preparation and that immediately. It is now extraction from soil, forests, mines, and waters, of not only foods, but of all sorts of material to be worked up into thousands of forms to meet man's expanded diversification of wants. It is the skilled and specialized preparation of all this raw material for final economic consumption in multitudes of varieties of factories and manufactories. It is the transportation of all this raw and formed material to and from mine and farm and factory and forest and thence to wholesalers and retailers. It is the wholesaling and retailing of this produce, raw and formed, to all buyers and consumers. It is the clerical, the financial, and the managerial activities which go along with these various lines of business and make them possible. Anyone who makes a business of life in any phase of this complicated industrial field and labors to produce to the satisfaction of the economic wants of the rest of society is professionalized, specialized, and vocationally economic. All other members of society are secondarily interested in his vocation to the extent that their wants are to be satisfied through him.

The cultural line of activities today is no longer simple as it was in traditionary times. It comprises in its organized scope, not only all systematic educative endeavors, but also all informational agencies represented in press and platform, clubs, societies, chautauquas, etc., and all aesthetic agencies. The religious phase is likewise differentiated into ecclesiastical denominations and sects, societies, organizations, and clubs.

In order that it may be clear what is the relation of the individual to the whole of society by means of these groups of social organizations the diagram is presented.

Let the circle represent the circumference which incloses the total society. $A$ is an individual so placed that he is shown to 
be in relation to each institutional area. The spaces between the parallel lines $B$ ending in $B^{\prime}, C$ ending in $C^{\prime}, D$ ending in $D^{\prime}$, etc., represent the great groups of organizations through which the dominant interests are realized. $A$ has his vocationally dominant interest in $B-B^{\prime}$, and works through it chiefly. But at times he acts or may act through the others, his relation to them and his use of them being subordinate to the relation and use of his vocational line.

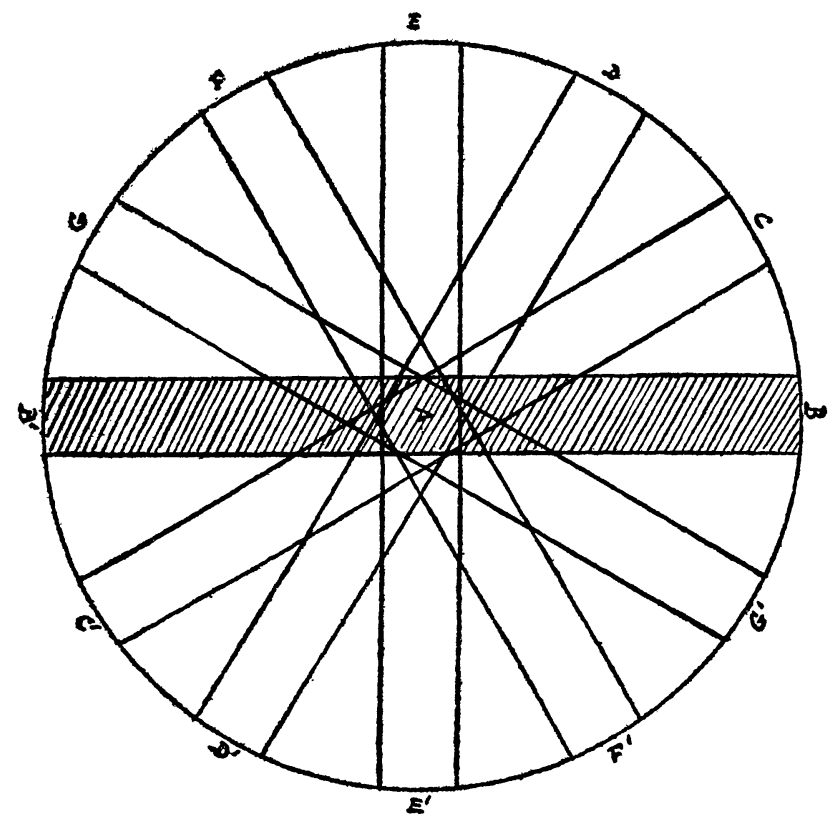

Several things are apparent at this point. First, society is a unity of specialized structures, each with a particular line of functions to perform which is necessary to its integral life, that is to say, the life of all the participative members. The perfection of this organic body, this unity of interdependent, co-operating structures, depends on the completeness and validity of each of the fundamental structures and subordinate organisms or groups. Should any one line become defective, or too large or too small relative to the other lines of activity, the equilibrium of the whole would be disturbed and its life impaired. This means the 
impairment of all other structures, and this in turn means the impairment of the lives of the individuals constituting these structures.

Second, the trend of society is toward more vocations. Society is a very definite affair instead of being as many suppose a great hazy, inchoate, lumbering lump of human protoplasm which may be butted into and attacked in any ill-considered and unspecialized manner. The significance of social evolution is that society becomes more and more specialized, breaks up into more vocations and divisions of labor, demands an increasing number of specialists to perform its functions. And, looking to the future, we must expect that this tendency is to continue and even to become more intense as scientific and business methods and organization expand and penetrate the mass.

Third, in order to be able to adjust himself, that is to be efficient, the individual must be specialized. Since society has developed into a great organization of specialties, it insists that its members shall be specialized that they may take part in the integral social process. Just as the physical organism finds no use for the cell which is not specialized to act as muscle, nerve, blood, or tissue cell, but attempt to rid itself of non-specialized cells when they appear in it, so society demands that each of its constituent members shall be skilled and trained into fruitful contributors in some group of its special structures. The least specialized, such as unskilled laborers, tramps, hoboes, and idle rich, are either not prepared to participate in the vital processes of society by reason of being little specialized or else refuse to take part according to their training. Ability to adjust oneself means just the possession of the technique of a certain structure or certain structures. These we have seen are occupational lines. Of course this does not mean that everyone must be a social philosopher or scientist or entrepreneur. Specialization means skill and technical ability in a given line. To have a trade or a profession is to be in possession of this specialization.

The bearing of the foregoing on education must have become apparent. If education as a process is training for society, then we know what it should be and do. For we have shown that 
training for society can have no other meaning than fitting to participate in the actual social process. And this participating in the social process means the social adjustment of the individual through and by means of the actual agencies and structures society has developed. Only those possessing the technique of vocational lines are fitted to make this adjustment.

The assumption of state education is that its training is necessary for citizenship, that is to be a valid member of society. But since one can be such only as he is able to function in society, that is work in society, according to its fundamental nature, and since society is essentially specialized and vocational in constitution, it follows that to make citizens in the best sense is to vocationalize them, to make them able to further some dominant social interest. To be unspecialized is really to be socially functionless, to be without a serviceable articulating position in the social organization. Logically, all ranks of those trained at the hands of the state are imperatively adjured so to fit themselves. Otherwise the state taxes those functioning, those who are productive socially, to give a general education, which means an unspecializing, decentralizing, distracting period of diffused cultivation, to those who will be floaters and parasites until by experience or further training they obtain a real working connection with society. When nine out of every ten children in the common schools of the United States are leaving school before the close of the period of elementary training it is evident that the state must insist that its future citizens shall be given just that specific culture which will most directly and effectively make them able to sustain a working, productive, self-supporting connection with itself.

The further question will arise about how the state or the individual shall decide what vocational lines to emphasize. Some answer should be given to this troublesome interrogation. There is good ground for thinking that the community interest affords the only rational guide to show what shall be taught.

The only practical criterion and therefore rational one at present to determine what sort of training a school in a given 
community should give is that of the dominant local interest or interests. A rational plan if practicable would be to establish a clearing-house of callings to give facts relative to the various vocational lines as to their supply of members. With such facts in hand, educational experts could advise those old enough to begin their vocational training what line to take up. This would suppose a diversity of training-courses in each school which, of course, could not be sustained, in rural regions at least, nor have we hardly the beginning of such a clearing-house of information.

Already we have seen the absurdity and destructiveness of maintaining educational plants in communities with well defined interests without recognition in the school being given toward preparing for those interests. Advanced nations, states, and communities are rapidly turning from this blind attitude.

The objection is heard against making the interest or interests of the community the criterion of what most to emphasize in its schools that our population is so migratory as to undermine the usefulness of the criterion. Why emphasize agriculture in an agricultural community if the pupils are to remove to urban communities to spend their days? And if our population were as migratory as the objectors suppose the criterion would be empty. To demonstrate that the criterion is valid and useful the following facts showing the relative stability of our population are given.

First, the population of the United States relative to the states is quite stable.

The total native-born population in 1900 was $65,767,45$ I (including Alaska and Hawaii, but excluding 75,85I native-born enumerated at military and naval stations abroad). Of this number $51,979,65$ I or 79 per cent. were born in the state or territory in which they were found by the census enumerators. The remaining $13,787,800$, constituting 21 per cent. of the entire native-born element, had migrated from the state or territory in which they were born and were found in the other states and territories. The proportion living in the state or territory of birth was slightly larger in 1900 than it was in 1890 (U. S. Statistical Atlas, 1900, p. 43).

With reference to the kind of communities the migrants settle in, that is the $2 \mathrm{I}$ per cent., anyone familiar with the history of settling 
the West and who has lived in various parts of the West knows that easterners move west and that they are mostly from rural regions. That is, farmers take up the new farming lands of the West more largely than any other class.

Second, the growth of cities touches the stability of the population relatively lightly and is largely accounted for by immigration. The growth of urban relative to rural population was only about 12 per cent. in a generation, or from 20.9 per cent. to $33 . \mathrm{I}$ per cent. between 1870 and I900 (ibid., p. 40). The largest increase is in commercial and industrial regions. Massachusetts has increased its urban population from 56 to 76 per cent.; Illinois, from 32 to 47 per cent.; Kansas, from I 2 to 28 per cent., from I870 to I900. Southern and newer western states and territories have increased their city inhabitants relative to rural little in that time (ibid., plate 20 ).

Immigrants from abroad throng the cities and largely make their excess growth. There are living in cities of 25,000 inhabitants and over, about 75 per cent. of Russians; 63 per cent. each of Poles, Italians, and Irish; nearly 60 per cent. each of Bohemians, Austrians, and Hungarians. These, except the Irish, are the foreign races which now most come to America (ibid., plate 73). A large part of those and other races settle in smaller industrial communities. Germans and Scandinavians mostly congregate in the northwesterly states as agriculturists and will likely remain such (ibid., plates 65, 69).

On the basis of these facts it is safe to state that probably somewhere near 90 per cent. of our citizens will remain in the original community, or that if they migrate it will be to a social group with similar interests to the old.

It is taken as a valid argument in education today that since over 90 per cent. of our youth will not remain in school beyond the elementary grades, our education in those grades should be made more vocational in nature. It would seem to be an equally valid argument to hold that since we can locate the future vocational interests of perhaps quite as large a portion of the youth the dominant interests of any community should serve as the guide in the kind of training the children of that community 
should have. This interest or the interests will determine the vocational element to place in the center of the training programme, the phases of the informational studies which are most needed for illuminants and supports of the vocational, and in connection with the ethical demands arising out of every community will form the cue to the kind of work to be done. 